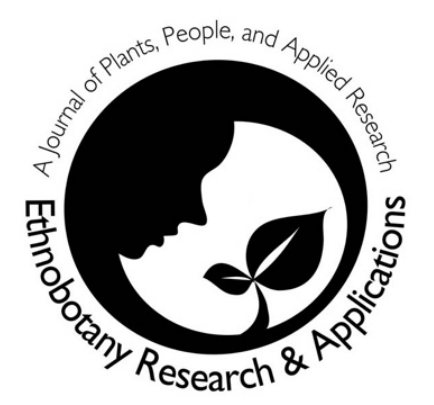

\title{
Medicinal plants used in male circumcision among the Bagishu of Eastern Uganda
}

\author{
Nakitende G. and Anywar G.
}

\author{
Correspondence \\ Nakitende G. and Anywar G. \\ Department of Plant Sciences, Microbiology \& Biotechnology, Makerere University, Kampala P. O. Box 7062 \\ *Corresponding Author: godwinanywar@gmail.com / ganywar@cartafrica.org /godwin.anywar@mak.ac.
}

Ethnobotany Research and Applications 23:13 (2022)

\section{Notes on Ethnobotany}

\begin{abstract}
Background: Plants have long been used in traditional medicine and in cultural practices such as circumcision. Circumcision is one of the oldest and most widely performed procedures globally. Although male circumcision among the Bagishu in Eastern Uganda has been widely studied, these studies have focused on social and cultural aspects of the ritual. No study has ever investigated the medicinal plant species used during the process despite their widespread use and importance.
\end{abstract}

Methods: An ethnobotanical study was conducted in Sironko district, in Eastern Uganda, to document the medicinal plants used by the Bagishu during the male circumcision ritual. Semi-structured questionnaires were used for data collection. Fifteen traditional practitioners were identified using the snowball technique and interviewed.

Results: Four medicinal plant were used in male circumcision, namely: Cissampelos mucronata A. Rich, Conyza sumatrensis (S.F. Blake) Pruski \& G. Sancho, Dracaena fragrans (L.) Ker Gawl, and Urtica massaica Mildbr. These herbs are either administered orally or applied topically on wounds. C. mucronata was the most frequently used plant for wound healing. It is also believed to give courage and embolden young men before circumcision.

Conclusion: The Bagishu use medicinal plants during circumcision rituals mainly for treating wounds and stopping bleeding. This knowledge is on the verge of being lost despite its potential economic and health benefits in terms of wound healing.

Key words: Traditional practitioners, male circumcision, medicinal plants, Uganda

\section{Background}

Plants have been used in traditional medicine for thousands of years and in cultural practices such as circumcision (Abu-Rabia 2005). Circumcision is the surgical removal of the foreskin covering the tip of the penis (Alanis and Lucidi 2004). It is one of the oldest and most widely performed procedures for religious, cultural, social, and medical reasons globally (Drain et al. 2006, Doyle 2005, Weiss et al. 2010). With advances in surgery in the $19^{\text {th }}$ century, and increased mobility in the $20^{\text {th }}$ century the procedure was introduced to other cultures (Alanis and Lucidi 2004). About one-third of males worldwide are estimated to have been circumcised (Weiss et al. 2010, WHO 2008). Today, male circumcision is recommended as an efficacious intervention for HIV prevention. It also promotes hygiene, and decreases the risk of urinary tract infections, penile cancer, and sexually transmitted infections (WHO 2008). 
Historically, male circumcision was practiced among ancient Semitic people including Egyptians and Jews. The earliest records depicting circumcision are on Egyptian temple and wall paintings dating from around $2300 \mathrm{BC}$ (Alanis and Lucidi 2004). Certain African cultural groups, such as the Yoruba and Igbo of Nigeria and Bagishu of Uganda, or individual family lines in the Sudan, Democratic Republic of Congo, and in southern Africa also practice male circumcision. However, even when circumcision is carried out for reasons of tradition, among these groups, it is often done in hospitals (WHO 2008).

In Uganda, male circumcision is culturally performed by the Bagishu, on boys usually between the age of 16-22 years. The elaborate ritual known as Imbalu initiates boys into manhood. This ritual also involves music and the Kadodi dance (Khamalwa 2004, Makwa 2006). The procedure of male circumcision is carried out by the local practitioners known as Umuchebi in Lugishu, using a sharp surgical knife known as lyembe or ipalu (Makwa 2006).

Although male circumcision in Uganda has been widely studied by different researchers, these studies have focused on the social and cultural aspects of the process. No study has ever been conducted to investigate which medicinal plants are used during the process, despite their widespread use and importance to the ritual. As a result, this knowledge is at risk of being lost. We therefore conducted this study to document, for the first time, the plants used during circumcision in Sironko district, in Eastern Uganda.

\section{Materials and Methods}

The study was conducted in Sironko district, Budadiri Sub County, in two parishes: Bukyambi and Mutufu. The Bagishu, who live along the slopes of Mountain Elgon, are the main inhabitants of these parishes. Sironko district, which is located at $01^{\circ} 14^{\prime} \mathrm{N} 34^{\circ} 15^{\prime} \mathrm{E}$, was carved out of Mbale district in 2000 . It covers an area of $446.1 \mathrm{k} \mathrm{m}^{2}$ and has a population density of $537.1 / \mathrm{km}^{2}$ (www.sironko.go.ug).

The snowball technique (Cohen and Arieli 2011) was used to identify and locate the key respondents who were local traditional local practitioners in the two parishes. Fifteen male traditional practitioners were interviewed. An interview guide with semi-structured questions was used to engage the practitioners.

\section{Plant identification}

Plant species mentioned in the study were identified in the field with the help of the practitioners. Voucher specimens of these plants were collected and deposited at the Makerere University herbarium for identification. The scientific names of the plant species were assigned based on the Kew database at http://www.theplantlist.org. accessed on $31^{\text {st }}$ August 2020 at 21:00. Plant families were verified using angiosperm phylogeny group III at http://www.mobot.org/MOBOT/research/APweb/.

\section{Results}

Fifteen male local practitioners, from the Mutufu and Bukyambi parishes, ranging in age from 50-75, were interviewed. Eighty percent of the respondents had completed primary education, and the remaining $20 \%$ had completed secondary education. The practitioners had obtained their knowledge from their grandparents $(73 \%)$ and from their parents (27\%). Most of the practitioners interviewed (93\%) were Muslim, the remainder $(7 \%)$ were Roman Catholic. Four plant species belonging to each of the following families: Menispermaceae, Asteraceae, Asparagaceae, and Urticaceae, were identified as being used in traditional male circumcision (Table 1); a fifth species, Pavonia patens, was also identified by three practitioners as being used occasionally, under specific circumstances. Cissampelos mucronata was the most frequently used species in the circumcision procedure with a frequency of mention of 12 , whereas the rest were mentioned only once.

\section{Preparation and administration of herbal remedies}

Three of the four plant species were administered by simply having the patient chew small pieces of fresh clean root. The roots were also crushed and applied to wounds. It is believed that chewing the roots of $C$. mucronata, $D$. fragrans and $U$. massaica before circumcision protects one from bad omens and provides strength and courage to the candidate. Leaves and flowers of Conyza sumatrensis are squeezed directly on the circumcised wound to stop bleeding before other measures are taken. Although the practitioners grew $C$. sumatrensis, $U$. massaica, and $D$. fragrans around their homesteads in small herb gardens, all these plant species grow wild. 
Table 1. Plant species used in the male circumcision in Sironko district

\begin{tabular}{|c|c|c|c|c|c|c|}
\hline $\begin{array}{l}\text { Scientific name } \\
\text { (Family) }\end{array}$ & $\begin{array}{l}\text { Local name } \\
\text { (Lugishu) }\end{array}$ & PU & $\mathbf{H}$ & Use of the plants & $\begin{array}{l}\text { Mode of } \\
\text { Administration }\end{array}$ & FM \\
\hline $\begin{array}{l}\text { 1. Cissampelos } \\
\text { mucronata A. Rich } \\
\text { (Menispermaceae) }\end{array}$ & Idyanyi & $R$ & $\mathrm{C}$ & $\begin{array}{l}\text { Heals wounds \& } \\
\text { emboldens circumcision } \\
\text { candidates }\end{array}$ & $\begin{array}{l}\text { Chew small piece of } \\
\text { root. Crush \&apply to } \\
\text { wound }\end{array}$ & 12 \\
\hline $\begin{array}{l}\text { 2. Conyza sumatrensis } \\
\text { (S.F. Blake) Pruski \& } \\
\text { G. Sancho } \\
\text { (Compositae) }\end{array}$ & Zikamama & $\mathrm{Fl} / \mathrm{L}$ & $\mathrm{H}$ & Stops bleeding & $\begin{array}{l}\text { Squeezed directly on } \\
\text { the wound }\end{array}$ & 1 \\
\hline $\begin{array}{l}\text { 3. Dracaena fragrans (L.) } \\
\text { Ker Gawl } \\
\text { (Asparagaceae) }\end{array}$ & Masinzi & $\mathrm{R}$ & $\mathrm{S}$ & $\begin{array}{l}\text { Wound management } \& \\
\text { cleaning before dressing }\end{array}$ & $\begin{array}{l}\text { Chew small piece of } \\
\text { root. Crush \& apply t } \\
\text { wound }\end{array}$ & 1 \\
\hline $\begin{array}{l}\text { 4. Urtica massaica } \\
\text { Mildbr (Urticaceae) }\end{array}$ & Litalika & $R$ & $\mathrm{H}$ & $\begin{array}{l}\text { Heals wounds \& } \\
\text { emboldens circumcision } \\
\text { candidates }\end{array}$ & $\begin{array}{l}\text { Chew small piece of } \\
\text { root. Crush \&apply t } \\
\text { wound }\end{array}$ & 1 \\
\hline
\end{tabular}

Key: L=Leaves, R=Roots, Fl=Flowers, S=Shrub, H=Habit, PU- Parts Used

\section{Discussion}

Most of the local practitioners interviewed were Muslims. The origin of circumcision in the region may be associated with circumcision as a religious ritual in Islam.

The popularity of $C$. mucronata as a wound-healing plant has also been reported in South Africa by De Wet and Van Wyk (2008). Cissampelos mucronata is the second most commonly used medicinal plant in southern Africa after C. capensis and is also widely used in the rest of Africa (De Wet 2006). The roots and leaves are widely used for treating genitourinary system disorders, wounds, infections, digestive system disorders, fever, infertility, and as a sexual stimulant (De Wet and Van Wyk 2007, De Wet and Van Wyk 2008, Von Koenen, 2001). Nwafor and Okoye (2008) showed the methanolic leaf extracts of $C$. mucronata to have antiulcer activity against indomethacin-induced ulcers that was comparable to the drug cimetidine. Cissampelos mucronata contains alkaloids, cardiac glycosides, tannins, saponins, flavonoids and steroids among others (Tanko et. al. 2007), and an ethanol extract of root tissue shows significant sedative activity (Akah et al. 2002).

The wound healing activity of $C$. sumatrensis is attributed to presence of the different phytocompounds it contains such as tannins, flavonoids, saponins, steroids, glycosides sesquiterpenoids, diterpenoids and cyclooctadienone derivatives (Boti et al. 2007, Jack and Okorosaye-Orubite 2008).

The leaves of $U$. massaica are used for treating erectile dysfunctions in western and southwestern Uganda (Kamatenesi-Mugisha \& Oryem-Origa 2005) but are also consumed as a wild vegetable (Musinguzi et al. 2006). The leaves of $U$. massaica are used to treat lesions and skin cancer in Kakamega, Kenya (Ochwang'i et al. 2014) and diabetes (Keter \& Mutiso 2012). Urtica massaica contains tannins, flavanoids, leucoanthocyanes, anthocyanes, quinines and terpenes, sterols (Renzaho 2007).

The leaves of Pavonia patens, a fifth species sometimes associated with the circumcision ritual, are only occasionally used during the circumcision season which occurs in the months of August to September and December to January (Makwa 2006). This is because few candidates are found to be already infected with sexually transmitted diseases. Additionally, those with sexually transmitted infections generally seek medical attention at nearby health facilities. Although there is little research on Pavonia patens in the context of wound healing, Pavonia odorata is used to treat ulcers, bleeding disorders and dermatitis in Indian Ayurvedic medicine (Khare 2007). Pavonia odorata shows anti-inflammatory and spasmolytic activities and the roots have an essential oil containing isovaleric acid, isovaleraldehyde, armomadendrene, pavonene, alpha-terpinene, azulene and pavonenol and have antiparasitic activity against Entamoeba histolytica (Khare 2007). However, the cytotoxicity and wound-healing properties of these plant species have not been studied (Anywar et al. 2021).

In conclusion, the Bagishu of Sironko, eastern Uganda use medicinal plants during the circumcision rituals mainly to treat wounds and stop bleeding. However, some of the plant species are believed to give courage to and 
embolden young men before the circumcision procedure. We recommend investigation of the wound healing potential and safety of these plant species.

\section{Declarations}

Abbreviations: WHO-World Health Organization

Ethical considerations: Ethical approval was obtained from the School of Biosciences, College of Natural Sciences, Makerere University. Prior informed consent was obtained from the local chiefs and practitioners before the study commenced. The aim of the study was explained to the participants before every interview and the respondents were informed that they were free to withdraw their consent any point during the study.

Consent for publication: Not applicable-no personal data are included in this manuscript.

Availability of data and materials: The data used to support the findings of this study are available from the corresponding author upon request.

Competing interests: The authors declare no competing interests.

Funding: This study has not received any grant/funding from any agencies or forum.

Author's contributions: Godwin Anywar supervised Gloria Nakitende as she conducted the study. Both authors contributed to writing the manuscript; Anywar reviewed and edited the final draft.

\section{Acknowledgement}

We are very grateful to the traditional practitioners in Mutufu and Bukyambi parishes in Sironko for their contributions as well as Dr. Dorothy Ndagire who helped in conceptualizing the study.

\section{Literature cited}

Abu-Rabia A. 2005. Urinary diseases and ethnobotany among pastoral nomads in the Middle East. Journal of Ethnobiology and Ethnomedicine:1(1):4.

Akah PA, Nwafor SV, Okoli CO, Egbogha CU. 2002. Evaluation of the sedative properties of the ethanolic root extract of Cissampelos mucronata. Bollettino Chimico Farmaceutico 141(3): 243-6.

Alanis MC, Lucidi RS. 2004. Neonatal circumcision: A review of the world's oldest and most controversial operation. National Center for Biotechnology Information, US National Library of Medicine: 59(5):379-395.

Anywar GU, Kakudidi EK, Byamukama R, Mukonzo JK, Schubert A, Oryem-Origa H, Jassoy C. 2021. A review of the toxicity and phytochemistry of medicinal plant species used by herbalists in treating people living with HIV/AIDS in Uganda. Frontiers in Pharmacology 12:435.

Boti JB, Koukoua G, N'Guessan TY, Casanova J. 2007. Chemical variability of Conyza sumatrensis and Microglossa pyrifolia from Côte d'Ivoire. Flavour and Fragrance Journal 22(1):27-31. doi: 10.1002/ffj.1743

Cohen N, Arieli. T. 2012. Field research in conflict environments: Methodological challenges and snowball sampling. Journal of Peace Research 48(4): 423-435.

De Wet $\mathrm{H}$, Van Wyk BE. 2008. An ethnobotanical survey of southern African Menispermaceae. South African Journal of Botany 74(1):2-9. doi: 10.1016/j.sajb.2007.07.001

De Wet H. 2006. An ethnobotanical and chemotaxonomic study of South African Menispermaceae. PhD Thesis, University of Johannesburg.

Doyle D. 2005. Ritual male circumcision: a brief history. The Journal of the Royal College of Physicians of Edinburgh 35(3):279-285.

Drain PK, Halperin DT, Hughes JP, Klausner JD, Bailey RC. 2006. Male circumcision, religion, and infectious diseases: an ecologic analysis of 118 developing countries. BMC Infectious Diseases. 6:172

Jack IR, Okorosaye-Orubite OK. 2008. Phytochemical analysis and antimicrobial activity of the extract of leaves of Conyza sumatrensis. Journal of Applied Science in Environmental Management 12(4):63-65.

Kamatenesi-Mugisha M, Oryem-Origa H. 2005. Traditional herbal remedies used in the management of sexual impotence and erectile dysfunction in western Uganda. African Health Science 5(1):40-49.

Keter LK, Mutiso PC. 2012. Ethnobotanical studies of medicinal plants used by Traditional Health Practitioners in the management of diabetes in Lower Eastern Province, Kenya. Journal of Ethnopharmacology 139(1):74-80. doi: 10.1016/j.jep.2011.10.014

Khamalwa WJP. 2004. Identity, Power and Culture: Imbalu initiation ritual among the Bamasaba of Uganda. Bayreuth African study series, 68: Pia Thielmann \& Eckchard Breitinger, Eckersdorf, Germany. 
Khare CP. 2007. Indian Medicinal Plants. An Illustrated Dictionary Springer-Verlag Berlin/Heidelberg, Germany.

Makwa DB. 2006. The role of music and dance in circumcision ceremonies among the Bagisu of Eastern Uganda. B.A (Music) Dissertation, Makerere University, Kampala.

Musinguzi E, Kikafunda JK, Kiremire BT. 2006. Utilization of indigenous food plants in Uganda: A case study of south-western Uganda. African Journal of Food Agriculture Nutrition and Development 6(2).

Nwafor SV, Okoye CF 2005. Antiulcer properties of the ethanol root extract of Cissampelos mucronata. Pharmaceutical Biology 43:5:396-403, doi: 10.1080/13880200590963222

Ochwang'i DO, Kimwele CN, Oduma JA, Gathumbi PK, Mbaria JM, Kiama SG. 2014. Medicinal plants used in treatment and management of cancer in Kakamega County, Kenya. Journal of Ethnopharmacology, 151(3):10401055. doi: 10.1016/j.jep.2013.11.051

Renzaho A. 2007. Contribution al etude phytochimique et del'activite antimicro-bienne desfeuillesd' Urtica massaica Mildbr(igisura). Butare 17-30.

Tanko Y, Yaro AH, Isa A, Yerima M, Saleh MIA, Mohammed A. 2007. Toxicological and hypoglycemic studies on the leaves of Cissampelos mucronata (Menispermaceae) on blood glucose levels of streptozocin-induced diabetic wistar rats Journal of Medicinal Plants Research 1(5):113-116.

Von Koenen E. 2001. Medicinal, poisonous and edible plants in Namibia. Klaus Hess Publishers, Windhoek, Namibia. Weiss HA, Larke N, Halperin D, Schenker I. 2010. Complications of circumcision in male neonates, infants and children: a systematic review. BMC Urology 10:2.

World Health Organization. 2008. Male circumcision: global trends and determinants of prevalence, safety and acceptability. (No. UNAIDS/07.29 E/JC1320E). WHO 